\title{
PARTAI DEMOKRASI INDONESIA PERJUANGAN DALAM PERSAINGAN POLITIK DI BALI TAHUN 1999-2019
}

\author{
I Wayan Agus Pebriana \\ Program Studi Ilmu Sejarah \\ Fakultas Ilmu Budaya Universitas Udayana \\ Email: aguspebriana1602@gmail.com
}

\begin{abstract}
ABSTRAK
Studi ini berusaha mengungkapkan mengenai Partai Demokrasi Indonesia Perjuangan (PDI-P) dalam persaingan politik di Bali tahun 1999-2019. Pergantian sistem kekuasaan dari Orde Baru ke Reformasi telah menghasilkan perubahan sistem politik yang signifikan. Pada politik tingkat lokal Bali terjadi pergeseran kekuatan politik. Sebelumnya pada masa Orde Baru kekuatan politik dikuasai oleh Golkar kini mulai beralih ke PDI-P. Adapun permasalahan yang dibahas dalam studi ini adalah (1) Bagaimana kiprah PDI-P dalam persaingan politik di Bali dari tahun 1999-2019 (2) Mengapa PDI-P berhasil tampil sebagai partai dominan dalam persaingan politik di Bali (3) Apa implikasi dari keberhasilan PDI-P tampil sebagai partai dominan di Bali. Penelitian ini menggunakan teori sejarah, terutama historical explanation dan historical causation serta dibantu teori dari ilmu sosial yakni Kepemimpinan dari Antonio Gramsci. Hasil penelitian ini menunjukan sepanjang pemilu paska runtuhnya Orde Baru, PDI-P berhasil tampil sebagai partai dominan di Bali dari tahun 19992019. Keberhasilan PDI-P tampil sebagai partai dominan di Bali tidak terlepas dari kesuksesan PDIP memanfaatkan modal simbolik masa lalu sebagai partai Soekarno, PDI-P juga berhasil membangun sistem aliansi dengan berbagai kelompok masyarakat yang memberi dukungan politik, serta PDI-P berhasil memperbaharui sistem pengorganisasian partai. Kesuksesan ini berimplikasi pada keberhasilan PDI-P untuk merealisasikan agenda-agenda partai.
\end{abstract}

Kata Kunci: PDI-P, Pemilu, Persaingan Politik, Dominasi

\begin{abstract}
ABSTRACK
This study seeks to reveal the Indonesian Democratic Party of Struggle (PDI-P) in the political competition in Bali in 1999-2019. The change in the power system from the New Order to the Reformation has resulted in significant changes in the political system. At the local political level in Bali there is a shift in political power. Previously, during the New Order era, political power was controlled by Golkar, now it has begun to shift to the PDI-P. The problems discussed in this study are (1) how was the PDI-P's role in political competition in Bali from 1999-2019 (2) Why PDI-P managed to emerge as a competitor in political competition in Bali (3) What was the competition from the success of the PDI -P emerged as the dominant party in Bali. This study uses historical theory, especially historical explanations and historical cause and effect as well as theoretical assistance from social science, namely Leadership from Antonio Gramsci. The results show that throughout the post-New Order election, PDI-P managed to emerge as the dominant party in Bali from 1999-2019. The success of the PDI-P to emerge as the dominant party in Bali is inseparable from the success of the PDI-P in utilizing the symbolic capital of the past as Soekarno's party, the PDI-P has also succeeded in building a system of alliances with various community groups that provide political support, and the PDI-P has succeeded in reforming the system. party organization. this had implications for the success of the PDI-P in realizing the party's agenda.
\end{abstract}

Keywords: PDI-P, Election, Political Competition, Domination 


\section{PENDAHULUAN}

Sampai sejauh ini kajian tentang kepartian di Bali sudah begitu banyak dituliskan, akan tetapi kajian yang membicarakan PDI-P masih minim dilakukan. Karya I Gede Indra Pramana (2015) dan Henk Schulte Nordholt (2010) sebetulnya sudah menyinggung PDI-P sebagai salah satu kekuatan politik di Bali. Dalam karyanya I Gede Indra Pramana (2015) memaparkan faktor-faktor yang mendorong munculnya PDI-P sebagai partai pemenang dalam pemilu paska Orde Baru. Salah satu faktornya adalah PDI-P sering dibandingkan sebagai PNI, partai yang identik dengan Soekarno ayahanda Megawati. Selain itu, Megawati mempunyai kedekatan emosional dengan masyarakat Bali, yang memuncak setelah menteri Pangan dan Holtikultural, AM Saefuddin, menyatakan Megawati tidak layak menjadi presiden karena bersembahyang di pura. Pada giliranya statemen ini mengundang reaksi dari masyrakat Bali.

Sementara itu, dalam karya Henk Schulte Nordholt (2010) mengungkapkan beberapa hal menarik terutama terkait konstalasi perpolilikan di Bali pasca reformasi 1998. Bagaimana demokrasi elektoral yang semakin terbuka dan kompetitif memungkinkan terjadinya perubahan konfigurasi politik di Bali. Hal ini dapat dilihat melalui pemilu 1999, dimana PDI-P dengan secara meyakinkan meraih suara $79,5 \%$ yang di waktu bersamaan menandai runtuhnya dominasi Golkar di Bali. Dalam karyanya juga, Henk Schulte Nordholt mengungkapkan bagaimana pertalian hubungan antara PDI-P dengan organisasi masyarakat (ormas) di Bali terbentuk, dimana Ormas ini berfungsi menyediakan dukungan publik.

Namun karena kedua karya tersebut tidak fokus membicarakan PDI-P dan sangat terbatas, terutama secara temporal. Maka dua karya itu tidak bisa memberikan penjelasan mengenai persaingan politik PDI-P di Bali. Berangkat dari hal tersebut maka studi ini bermaksud untuk melanjutkan sekigus melengkapi dua karya di atas dengan mengambil tema sejarah politik dengan topik Partai Demokrasi Indonesia Perjuangan (PDI-P) dalam persaingan politik di Bali.

Tabel 1

Perolehan Kursi Partai Demokrasi Indonesia Perjuangan (PDI-P) di DPRD Provinsi Bali

\begin{tabular}{|c|c|c|}
\hline No & Tahun Pemilu & Jumlah Perolehan Kursi \\
\hline 1 & 1999 & 39 \\
\hline 2 & 2004 & 30 \\
\hline 3 & 2009 & 24 \\
\hline 4 & 2004 & 24 \\
\hline 5 & 2019 & 33 \\
\hline
\end{tabular}

Sumber: Komisi Pemilihan Umum Provinsi Bali

Pergantian kekuasaan dari pemerintah Orde Baru ke Era Reformasi telah membawa perubahan signifikan dalam kehidupan politik di Indonesia. Pada politik tingkat lokal Bali terjadi pergeseran kekuatan politik, dimana sebelumnya pada era pemerintahan Orde Baru didominasi oleh Golkar kini mulai beralih ke PDI-P. Sepanjang pemilu paska runtuhnya Orde Baru, PDI-P sukses tampil menjadi partai 
dominan di Bali. Pada pemilu 1999, PDI-P berhasil memperoleh 39 kursi anggota dewan provinsi Bali dan sekaligus berhasil menggeser dominasi partai Golkar di Bali. Pemilu 2004 PDI-P memperoleh 30 kursi anggota dewan. Selanjutnya pada pemilu 2009 PDI-P mendapat 24 kursi anggota dewan. Jumlah perolehan kursi PDIP pada 2009 bertahan di pemilu 2014. Kemudian mengalami kenaikan pada 2019 dengan memperoleh 33 kursi anggota dewan.

Selain berhasil menguasai perolehan kursi legislatif, PDI-P juga sukses menguasai kursi kepala daerah, dalam hal ini Gubernur Bali. Sepanjang pemilihan kepada daerah (Pilkada) dalam rentang waktu 1999-2019. PDI-P beberapa kali mendudukan kader terbaiknya menjadi gubernur Bali. Pada Pilkada Bali tahun 2008, melalui mesin politiknya PDI-P berhasil mendudukan I Made Mangku Pastika dan A.A Puspayoga sebagai Gubernur dan Wakil Gubernur Bali. Keberhasilan serupa juga diteruskan PDI-P dengan memenangkan I Wayan Koster dan Tjokorda Artha Sukawati dalam pilkada Bali 2018.

Berdasarkan uraian di atas terdapat persoalan menarik yang perlu dibahas dalam studi ini yakni sekalipun perolehan suara PDI-P mengalami penurunan terutama pada hasil pemilu 2004 dan 2009. Akan tetapi PDI-P tetap berhasil muncul sebagai partai dengan suara dominan di Bali dengan mengalahkan partai-partai lain dalam persaingan politik di Bali tahun 1999-2019. Keberhasilan PDI-P muncul sebagai partai dominan dalam kontestasi perpolitikan di Bali tidak dapat dipisahkan dari taktik dan strategi politik yang ditempuh partai. Termasuk didalamnya terkait pengelolaan sumber daya, relasi, serta beragam isu dan wacana yang dibangun serta diproduksi partai.

Akan tetapi pernyataan ini baru merupakan suatu simpulan sementara, yang supaya menjadi simpulan tetap akan dilakukan penelitian melalui tiga rumusan masalah sebagai berikut: (1) Bagaimana kiprah PDI-P dalam persaingan politik di Bali dari tahun 1999-2019? (2) Mengapa PDI-P berhasil muncul sebagai partai dominan dalam persaingan politik di Bali tahun 1999-2019? (3) Apa Implikasi dari tampilnya PDI-P sebagai partai dominan dalam persaingan politik di Bali tahun 1999-2019?

\section{METODE PENELITIAN}

Dalam penelitian ini akan digunakan metode sejarah sebagai suatu prosedur dan langkah sistematis dalam proses mengumpulkan, menguji dan menganalisis secara kritis sumber sejarah. Metode sejarah dapat dibagi atas empat tahapan (1) Heuristik (2) Kritik (3) Interpretasi dan (4) Historyografi.

Dalam pengumpulan sumber-sumber penelitian, penulis menggunakan data-data berupa wawancara, dokumen, koran, arsip, serta sumber pustaka yang berkaitan dengan penelitian ini.

\section{KERANGKA TEORITIS}

Teori Sejarah meliputi historical understanding, historical explanation, historical objectivy, historical causation, dan historical determinism (Sidemen, Widya Pustaka, Tahun VIII No.2, Januari 1991: 32-48). Dari kelima teori sejarah 
tersebut, didalam studi ini hanya akan menggunakan dua diantanya ; pertama, historical explanation yakni pengumpulan bukti sejarah lalu menempatkanya dalam keterkaitan intrinsik kemudian dihubung kaitakan dengan konteks sejarah. Kedua, historical causation, yang berangkat dari premis tidak ada sebab tunggal dalam peristiwa sejarah. Kedua teori dalam Ilmu sejarah ini dinilai relevan sebagai kerangka berpikir untuk dapat menjawad dan menganalisis topik permasalahan dalam studi penelitian ini.

Menurut Sartono Kartodirdjo, teori sejarah dapat digunakan untuk menerangkan pertanyaan introgatif, yaitu, apa, kapan, dimana, dan bagaimana suatu peristiwa terjadi. Sementara, untuk menjawab suatu peristiwa itu terjadi, maka diperlukan bantuan teori ilmu sosial. Fungsi teori ilmu sosial dalam ilmu sejarah adalah untuk menganalisis faktor-faktor, kondisional, kontekstual, unsur-unsur komponen dan eksponen (Sartono, 1992: 2-3). Atas arahan tersebut maka dalam studi ini akan juga menggunakan teori dari ilmu sosial yaitu teori Kepemimpinan dari Antonio Gramsci.

Teori ini dibangun berdasarkan premis pentingnya ide dan tidak mencukupi kekuataan fisik belaka dalam melakukan kontrol politik (Sugiono, 2006; 31). Gramsci melihat begitu pentingnya suatu kelompok untuk menjalankan perang posisi yakni serangkian perang yang ditunjukan untuk mengeyahkan ideologi, norma, mitos, politik dan kebudayaan atau dengan kata lain perang posisi adalah proses tranformasi kultural untuk menghancurkan sebuah hegemoni lama dan digantikan dengan hegemoni baru. Dalam perang posisi, kelompok intelektual organik dari kelompok yang mencita-citakan hegemoni tidak hanya memproduksi dan menyebarluaskan ide tapi juga menguniversalkan dan meyakinkan ide tersebut untuk diterima oleh masyarakat sebagai sebuah keyakinan.

Perang posisi ini berlangsung pada masyarakat sipil yang dalam konsep Gramscian mencakup semua apa yang disebut organisasi-organisasi swasta (private) seperti gereja, serikat dagang, sekolah, partai politik, sekolah dan asosiasi budaya yang berbeda dari proses produksi dan aparat negara (Roger Simon, 2004; 102). aparatus-aparatus tersebut memainkan peran sangat signifikan dalam membentuk kesadaran massa, maka kemampuan kelompok-kelompok berkuasa dalam melestarikan kontrol sosial dan politiknya atas kelompok-kelompok lain sepenuhnya bergantung pada kemampuanya mengontol aparatus-aparatus tadi. (Sugiono, 2006; 35)

Hegemoni tidak pernah dapat diperoleh begitu saja, tetapi harus diperjuangkan secara terus menerus. Pengertian ini menegaskan bahwa hegemoni kelompok tertentu tidak pernah dalam kondisi stabil, ia selalu dipertanyakan, digugat, dan dilawan melalui beragam bentuk resistensi politik. Oleh karenya kepemimpinan moral dan intelektual harus tetap dipertahankan dan dikuatkan, serta segala macam resistensi akan dicari solusinya. Dalam hal mempertahankan hegemoni, Gramsci melihat pentingnya membangun sebuah sistem aliansi (blok historis) kepada kelompok sosial lain dalam rangka mempertahankan kontrol sosial dan politik. Aliansi bisa dilakukan kepada kelompok-kelompok sosial seperti petani, buruh, partai, organisasi pemuda, lembaga agama, lembaga pendidikan, yang mempunyai peran signifikan penting dalam masyarakat dan bisa mempengaruhi kesadaran masyarakat. 
Melalui kerangka berpikir Antonio Gramsci ini dapat membantu untuk menganalisis faktor-faktor terkait dengan keberhasilan PDI-P muncul sebagai partai dominan dalam persaingan politik di Bali.

\section{HASIL DAN PEMBAHASAN \\ Kiprah Politik PDI-P Di Bali Tahun 1999-2019}

Pergantian kekuasaan dari pemerintahan orde Baru ke Era Reformasi memberi pengaruh signifikan pada sistem politik Indonesia. Hadirnya gelombang demokratisasi, memberikan ruang seluas-luasnya bagi munculnya partai-partai politik baru di Indonesia. Perubahan politik secara cepat tersebut segera diantisipasi oleh para tokoh PDI yang masih berpihak kepada Megawati. Konsolidasi partai segera digalang, lalu kemudian dilanjutkan dengan penyelenggaraan kongres PDI di Bali pada tanggal 8-10 Oktober 1998. Salah satu keputusan penting kongres Bali adalah merekomendasikan pergantian nama menjadi Partai Demokrasi Indonesia Perjuangan (PDI-P) dengan maksud membedakanya dengan PDI pimpinan Soerjadi (Imran Hasibuan et al., 2015: 121-122).

Paska kongres di Bali, PDI-P mulai mempersiapkan diri untuk menghadapi pemilihan umum yang akan digelar pada 7 Juni 1999. Di Bali, PDI-P mulai masif membentuk struktur partai pada tingkat terkecil yang disebut Pimpinan Anak Cabang (PAC) untuk tingkat kecamatan dan Ranting untuk tingkat desa. Hal ini dilakukan untuk memobilisasi dan memperkenalkan PDI-P di tingkat masyrakat terbawah. Dalam rangka kampanye serta sosilisasi lambang dan logo partai, PDIP menggandeng grup musik Yong Sagita dan lawak Petruk untuk turun ke daerahdaerah dalam acara berbentuk pagelaran musik.

Dalam upaya meredam pengaruh Golkar di Bali, PDI-P melalui juru bicaranya lantang menyalahkan pemerintah Orde Baru dan mesin politiknya partai Golkar atas krisis yang menimpa Indonesia. Disamping juga, lantang berkampanye soal anti politik uang yang tujuanya menyasar dan menggembosi kekuatan partai Golkar.

Dalam sertiap kampanyenya PDI-P menggambarkan dirinya sebagai partai wong cilik dan diidentikan sebagai inkarnasi PNI, partai yang identik dengan Soekarno, ayahanda Megawati. Sebagai martir Orde Baru Megawati adalah simbol orang miskin dan tergusur, Popularitasnya mengalami kenaikan menginjak akhir dari pemerintah Orde Baru, begitu pula diikuti dengan PDI-P sebagai partai yang ia pimpin. PDI-P berhasil tampil sebagai partai pemenang pemilu 1999 di Bali dengan mengantongi 39 kursi anggota dewan. Perolehan ini mengakibatkan terjadinya gempa politik di Bali dimana suara Golkar anjlok sementara PDI-P melonjak signifikan (Henk Schulte Nordhold, 2010: 20).

Menyambut pemilu 2004, PDI-P dihadapkan pada persoalan rumit. Sebagai partai pemenang pemilu 1999, PDI-P dianggap sebagai partai pemerintah. Kinerja pemerintahanya disorot dan rakyat menunggu sejauh mana keberpihakan partai wong cilik kepada rakyat. Berstatus sebagai partai berkuasa menjadikan PDI-P semacam medan pertarungan dalam memperebutkan tiket calon legislatif yang menyebabkan terjadi konflik internal dalam tubuh partai. Para kader yang mendapati urutan peringkat terbawah memobilisasi para pendukungnya menyerang kantor-kantor partai dan membakar panji-panji partai. Persoalan-persoalan ini 
rupanya memberikan dampak signifikan melalui penurunan dukungan suara terhadap PDI-P pada pemilu 2004. Pemilu 2004 PDI-P hanya bisa memperoleh 30 kursi anggota dewan.

Keterpurukan PDI-P dalam persaingan politik di Bali berlanjut pada pemilu 2009. Pemilu 2009 yang menawarkan tarung bebas dan kehadiran partai politik seperti Gerindra sebagai penantang baru, menjadikan pertarungan politik semakin kompetitif. PDI-P hanya berhasil mengantongi 24 kursi anggota dewan pada pemilu 2009. Kendati mengalami penurunan perolehan suara, PDI-P tetap berhasil tampil sebagai partai dominan di Bali.

Paska penurunan perolehan suara dalam dua pemilu terakhir, yaitu pemilu 2004 dan 2009, menjadikan pemilu 2014 sebagai medan ujian cukup berat bagi PDI-P untuk eksis kembali. Secara nasional PDI-P memiliki dua modal politik cukup berarti menyambut pemilu 2014. Pertama, keputusan untuk bersikap sebagai partai oposisi. Kedua, menguatnya wacana Joko Widodo maju sebagai calon presiden usungan PDI-P. dua modal tersebut sedikit banyaknya memberikan keuntungan politik bagi PDI-P, terutama untuk meningkatkan citra dan popularitas partai. Perolehan suara nasional memperlihatkan PDI-P berhasil menduduki peringkat teratas. Sementara di Bali suara PDI-P mampu dipertahankan dengan meraih 24 kursi anggota dewan kembali.

Tren kemenangan PDI-P berlanjut pada pemilu 2019. Hal ini tidak terlepas dari keberhasilan PDI-P untuk meningkatkan perolehan suara partai. Pada pemilu 2019 di Bali, PDI-P berhasil mengamankan 33 kursi anggota dewan. Soliditas dalam tubuh partai diikuti dengan tata kelola pengorganisasian menjadi faktor determinan keberhasilan PDI-P. disamping juga PDI-P mendapatkan keuntungan elektoral atas pencalonan Joko Widodo kembali sebagai presiden. Keberhasilan ini sekaligus meneguhkan status PDI-P sebagai partai dominan di Bali.

\section{Faktor-Faktor Yang Mempengaruhi Munculnya PDI-P Sebagai Partai Dominan di Bali Tahun 1999-2019}

Keberhasilan PDI-P muncul sebagai partai dominan di Bali dari tahun 19992019 tidak terlapas dari faktor sejarah, terutama posisi PDI, sebelum menjadi PDIP, sebagai partai oposisi pemerintah Orde Baru. Tampilnya PDI menjadi partai oposisi dengan mengkritisi kebijakan-kebijakan pemerintah Orde Baru telah meningkatkan popularitas partai dikalangan masyarakat yang kecewa terhadap keberlangsungan pemerintahan Orde Baru. Sekalipun pilihan sikap politik ini kemudian berisiko mahal diakibatkan partai mulai diintervensi oleh kekuasaan yang berujung pada dualisme kepemimpinan partai antara PDI Megawati dan PDI Soerjadi. PDI Megawati yang tersingkir mendapatkan antusiasme dari masyarakat luas dan secara bersamaan mendongkrak popularitas partai. PDI-P dianggap sebagai inkarnasi PNI, partai yang identik dengan Soekarno. Hal ini tidak terlapas dari status Megawati sebagai anak Soekarno (Indra Pramana, 2015: 67). Hubungan kekerabatan ini pula yang berpengaruh mendongkrak suara PDI-P di Bali pada pemilu 1999. Sebagai orang yang memiliki keturunan darah Bali, Megawati merupakan representasi dari minoritas orang Bali dalam politik nasional.

Selain faktor berupa modal simbolik sebagai partai Soekarno, faktor lain dari keberhasilan PDI-P untuk tetap tampil sebagai partai dominan adalah 
kesuksesan PDI-P dalam membentuk aliansi bersama organisasi masyarakat (Ormas), salah satunya seperti Forum Peduli Denpasar (FPD), Dewan Pimpinan Massa (DPM), serta tokoh-tokoh Baladika Bali. PDI-P juga berhasil membangun hubungan dengan puri-puri lokal di Bali yang masih memiliki pengaruh dalam masyarakat Bali. Hubungan aliansi dengan berbagai kelompok lapisan masyarakat Bali ini, sedikit banyaknya memberikan keuntungan berupa dukungan politik kepada PDI-P.

Faktor lainya yang mempengaruhi dominasi PDI-P di Bali adalah kemampuan partai merespon tantangan zaman, PDI-P berhasil memperbaharui sistem pengorganisasian partai dengan membentuk saluran organik di struktur partai berupa organisasi-organisasi sayap yang dapat meningkatkan kerja dan gerak partai. Organisasi yang dimaksud seperti BMI, Bamusi, Gerakan Tani Perjuangan, Taruna Merah Putih, dan Relawan Perjuangan Demokrasi.

\section{Implikasi PDI-P Muncul Sebagai Partai Dominan di Bali}

Implikasi dari keberhasilan PDI-P muncul sebagai partai dominan di Bali adalah kemudahan dalam merealisasikan agenda-agenda partai baik dalam bidang hukum, sosial, dan ekonomi. Berbekal kekuatan politik mayoritas kursi DPRD, PDI-P memiliki ruang untuk menjalankan kontrol politik. Ide-ide yang sebelumnya digodok di dalam internal partai, berhasil dituangkan dan diperjuangkan di ruangruang sidang DPRD untuk diterbitkan menjadi sebuah Peraturan Daerah atau Peraturan Gubernur, terutama kader-kader partai yang berposisi sebagai kepala daerah.

Implikasi berikutnya, terciptanya kelompok masyarakat binaan di daerah pemilihan kader-kader PDI-P. Dalam rangka menjaga komunikasi politik, PDI-P mewajibkan kader-kader partai untuk aktif terlibat bersama masyarakat. Kebijakan partai ini tentu akan berdampak, terutama dalam upaya pemberdayaan masyarakat seperti melakukan pendidikan politik, bantuan sosial, serta hal-hal yang berkaitan dengan advokasi.

\section{SIMPULAN}

Berdasarkan masing-masing dari pertanyaan penelitian maka telah diperoleh tiga kesimpulan, sebagai berikut:

Pertama, sepanjang pemilu paska Orde Baru dari tahun 1999-2019 di Bali. Kendati mengalami penurunan perolehan suara terutama terjadi pada tahun 2004 dan 2009. Akan tetapi PDI-P mampu tetap konsisten tampil sebagai partai dominan dalam persaingan politik di Bali.

Kedua, faktor-faktor penting bagi PDI-P untuk tetap tampil sebagai partai dominan tidak terlepas dari modal simbolik sebagai partai Soekarno. PDI-P berhasil membangun sistem aliansi bersama kelompok-kelompok seperti organisasi masyarakat (ormas) dan puri yang menyediakan dukungan politik untuk PDI-P. Selain itu, PDI-P berhasil memperbaharui pengorganisasian partai dengan membentuk saluran organik dalam struktur partai sebagai sayap-sayap partai sehingga mudah diterima oleh masyrakat.

Ketiga, implikasi dari keberhasilan PDI-P tampil sebagai partai dominan adalah kemudahan PDI-P untuk merealisasikan agenda-agenda partai baik dalam 
bidang hukum, sosial, dan ekonomi. Demikian juga Implikasi lainya adalah terciptanya kelompok masyarakat yang menjadi binaan kader-kader PDI-P di setiap daerah pemilihan.

\section{Referensi}

Imran Hasibuan, et al. 2015. Gerak Sejarah Partai Banteng PNI, PDI, PDI Perjuangan Jakarta: DPP PDI Perjuangan dan Q Communication.

Kartodirjo, Sartono. Pendekatan Ilmu Sosial Dalam Metodelogi Sejarah. Jakarta: PT Gramedia Pustaka, 1992.

Nordholt, Henk Schulte. 2010. Bali Benteng Terbuka 1995-2005. Denpasar: Pustaka Larasan.

Simon, Roger. 2004. Gagasan-Gagasan Politik Antonio Gramsci. Yogyakarta: Pustaka Pelajar.

Sugiono, Muhadi. 2006. Kritik Antonio Gramsci Terhadap Pembangunan Dunia Ketiga. Yogyakarta: Pustaka Pelajar

Sidemen, Ida Bagus. "Lima Masalah Pokok Dalam Teori Sejarah,” widya pustaka edisi Tahun VIII Nomor 2 Januari 1991. Denpasar: Fakultas Sastra Universitas Udayana, 1991

Indra Pramana, Gede. "Politik Aliran Di Bali Pasca Soeharto", Government: Jurnal Ilmu Pemerintahan, 8 (7). 